Vernyhora Svitlana,

Candidate of Sciences on Social Communications, Associate Professor, Institute of Journalism

of Borys Grinchenko Kyiv University
Вернигора С. М.,

канд. наук із сои. комунік., доцент, Інститут журналістики Київського університету імені Бориса Грінченка

UDC 007: 304: [659.1+659.4]: 374.7

\title{
METHODS OF TEACHING VOCATIONAL SUBJECTS \\ IN ENGLISH AT THE INSTITUTE OF JOURNALISM OF BORYS GRINCHENKO KYIV UNIVERSITY
}

\section{МЕТОДИКА ВИКЛАДАННЯ ФАХОВИХ ДИСЦИПЛІН АНГЛІЙСЬКОЮ МОВОЮ В ІНСТИТУТІ ЖУРНАЛІСТИКИ КИЇВСЬКОГО УНІВЕРСИТЕТУ ІМЕНІ БОРИСА ГРІНЧЕНКА}

\begin{abstract}
Methods of teaching vocational subjects in English at the Institute of Journalism of Borys Grinchenko Kyiv University are presented in the research. Methods of realization of such a practice are shown through the example of disciplines of specialty "Advertising and public relations", in particular "Advertising copywriting", "PR copywriting", "Public service announcement", "Theory of mass information", "Communication strategies".

Keywords: methodology, methods, teaching, competencies, advertising and public relations, vocational subjects in English.
\end{abstract}

Анотащія. У публікації представлена методика викладання фахових дисциплін англійською мовою в Інституті журналістики Київського університету імені Бориса Грінченка. Методи реалізачї зазначеної практики продемонстровані на прикладі дисциплін спеціальності «Реклама $i$ зв'язки з громадськістю»: «Копірайтинг $y$

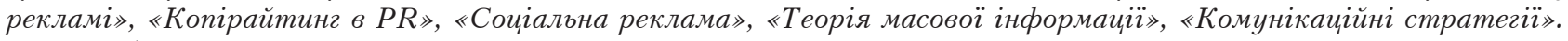
Ключові слова: методика, методи, викладання, компетентності, реклама $i$ зв'язки з громадсъкістю, фахові дисципліни англійською мовою.

I ntroduction. Appearance and rapid development of information technologies, emergence of such phenomena as globalization, information society created a significant impact on the future strategy of almost all areas of human activity. In particular, they influence on education system and fundamentally change it. Today an expert must have skills of his or her professional sphere as well as additional knowledge. Especially it concerns experts in advertising and public relations, because effective communication is an essence of their work. The requirements to the representatives of noticed sphere are experience in negotiations, ability to find common ground with advertisers, practical acquaintance with a business language, communication abilities, initiative, proficiency in English [1]. According to these requirements activity in the sphere of advertising and public relations includes professional knowledge as well as linguistic.

Problems of integration of vocational nonlinguistic and linguistic subjects were studied by such foreign researchers as D. M. Brinton [2], D. Coyle [3], B. A. De Escorcia [4], P. Hood [3], T. Hutchinson [5], I. Mackenzie [6], D. Marsh [3], A. Snow [2], A. Waters [5], M. B. Wesche [2] as well as scientists of post-Soviet countries such as I. Zvieriev [7], P. Kulahin [8], V. Maksymova [7], and in particular such Ukrainian authors as A. Brandt [9], S. Kozhushko [10], O. Tarnopolskyi [10].

Described earlier modern requirements to future specialists and the constant increase in the number of students of the Institute of Journalism of Borys Grinchenko Kyiv University, who wish to study vocational subjects in English, determine the topicality of this research. The purpose of publication is to describe methods of teaching vocational subjects in English at the Institute of Journalism of Borys Grinchenko Kyiv University and their analysis. Therefore, the tasks of the study are to describe the process of teaching vocational subjects in English, to present methods of realization of such a practice, to identify competencies that a student gets after training. 
Research methods. Descriptive method was used for the presentation of teaching vocational subjects in English. Primary methods were applied to collect data and to study sources. Common methods of scientific knowledge, in particular they belong to the methods of theoretical and empirical researches, such as comparison and analysis, helped to analyse the experience of different educational practices in teaching vocational subjects in English. The methods of transition from the abstract to the concrete were used at the theoretical level of the study.

Results and discussion. At the beginning of research, it is necessary to notice that the concept of teaching vocational subjects in English is not identified as a translation of texts with specific terminology into one of the languages. This is not a translation, but a communication within a non-linguistic discipline, where English plays role of communication tool. This refers to the interdisciplinary communication - interaction of chosen vocational subject and English, that is to say the content of vocational subject is transmitted through the English language, and it gives student a possibility to improve English. The researchers P.G. Kulahin, I. D. Zvieriev, V. M. Maksymova describe it as an integration of vocational non-linguistic and linguistic disciplines. Integration - process and result of creation of inextricably connected, unified study which is realized with the help of fusion of elements of different subjects, scientific notions and methods of teaching different disciplines in general scientific notions and methods; combination of basic parts of several disciplines for consideration of interdisciplinary study problems in one synthesized course (topic, chapter, program); it is a process of rapprochement and connection of sciences as well as a process of differentiation [7;8].

The Chair of Advertising and Public Relations of the Institute of Journalism of Borys Grinchenko Kyiv University provides study in English of such disciplines as "Advertising copywriting", "PR copywriting", "Public service announcement", "Theory of mass information", "Communication strategies". In this case, English is the instrument of learning advertising and PR disciplines.

O. B. Tarnopolskyi calls such an instrument "sublanguage of speciality" ("pidmova spetsialnosti"), a term that was proposed by V. A. Artemov in 1969. O. B. Tarnopolskyi interprets this term as a part of national language that isn't nationwide and serves certain professional sphere, providing its oral and written communication with the purpose of achievement of important professional goals and solution of tasks [10].

The authors of publication "Interdisciplinary coordination during teaching professionally oriented English and vocational subjects" call a process of teaching vocational subjects with the help of foreign language an interdisciplinary coordination and explain it as a regular dynamic various connection in training of foreign language of professional orientation and vocational subjects that define special vocabulary for communication in certain professional field [11].

As to our case, it refers to the interdisciplinary coordination of advertising, PR and linguistic disciplines, which began in February 2015 and was defined by initiators as an educational experiment. "Copywriting" was the first discipline that was proposed to teach in English. The students of the first year of study of fulltime education of the speciality "Advertising and public relations" became participants of such an experiment. Students received an offer to study the discipline "Copywriting" in English during practical session. Students who wanted to participate in such a practice passed a test of proficiency in English. The students of the first year of study consisted of two academic groups - RZHb-1-14-4.0d, RZHb-2-14-4.0d and the total quantity of students was 50 persons. According to the results of the test the group of students was formed to learn "Copywriting" in English during practical session. The group consisted of 13 students. It was $26 \%$ of total quantity.

As of December 2016 the teaching vocational subjects in English is based on five disciplines for students of the first and senior years of specialty "Advertising and public relations" and 50\% of students of each academic group have a relevant knowledge of English and desire to learn them. Students accept such a model of studying as have to, because, for example, students of the first year of study of speciality "Advertising and public relations" were informed during university admissions process concerning an opportunity to study vocational subjects in English. For some applicants this opportunity became decisive that to file the Institute of Journalism of Borys Grinchenko Kyiv University in the summer of 2016. It proves that the educational experiment became a necessity for students who attend the Ukrainian higher education institution. In this regard, we suggest considering methods of teaching vocational subjects in English.

Study of advertising and PR disciplines in English at the Institute of Journalism of Borys Grinchenko Kyiv University is realized on the base of programs to these disciplines. Theoretical aspects of a specialized discipline are considered during lectures in Ukrainian. It is caused by curriculum and methodological recommendations for educational process. In particular, lectures are given together for one class, so students can't be divided into subgroups. Synthesis of different disciplines (advertising or PR and linguistic) appears during practical lessons and final modular controls, where students are divided into Ukrainian and English-speaking subgroups. A separate part of educational material of each discipline is supposed 
for student's individual work. Students also work with it in Ukrainian or English-speaking subgroups.

If we talk about methods of teaching a foreign language, they can be gathered in three main groups: classical, communicative and non-traditional. Classical methodology provides a regular and gradual process of learning a foreign language, which is based on the following fundamental components as listening, grammar, reading and speaking. Communicative methodology is now considered as one of the most popular and it focuses on speaking and listening. The main purpose of this methodology is a formation of communication skills. Non-traditional methodology is oriented on an intensive study of foreign languages with the help of activation of the reserve human capacities, for example, to remember a large amount of material in a very short time [9].

Taking into consideration all the disadvantages and advantages of noticed language methods, communicative methodology was chosen to integrate with methodologies of advertising and PR disciplines with the aim to teach specialized subjects in English at the Institute of Journalism of Borys Grinchenko Kyiv University. There is a language situation in the center of attention that is defined by a content of specialized discipline. The purpose of teaching advertising and PR disciplines in English is to provide simultaneous learning vocational subjects and acquisition of language skills of noticed language through communication.

The methodology of teaching advertising and PR disciplines in English during practical session is realized with the help of two ways:

1. Methods of organization and implementation of educational and cognitive activities;

2. Methods of stimulation of interest and motivation of learning and cognitive activities.

In particular, the first way includes methods of organization and realization of educational and cognitive activities, which are based on:

- source of information. These methods are verbal, which mean an explanation, a narration, a conversation; visual - an observation, a use of illustrations, a demonstration; practical - an analysis;

- logic of transmission and reception of educational information. There are inductive, deductive, analytical, synthetic methods of training;

- degree of independence of thought. It concerns reproductive, search, research methods;

- degree of management of learning activity: under the guidance of an educator; individual work of students with educational materials; preparation of individual tasks.

The second way represents methods of stimulation of interest in learning such as educational discussions, creation of situation of cognitive innovation, creation of situations of interest (analogue method, etc). According to I. Mackenzie, the second way is the most corresponding for integration in the situation of study of vocational subjects with the help of a foreign language. His position is that content and language integrated education rather stimulates the mastery of foreign language than forces learning process; students can be motivated, when an authentic language and interesting content that is related to the subject of their training are on the focus, but not a language as such (grammar, functions, structure, etc.); students learn language during its usage as a teaching tool, but not as a theoretical material, for example, how to use language [6].

There are the main types of practice that are used during study of advertising and PR disciplines in English at the Institute of Journalism of Borys Grinchenko Kyiv University.

The case method is an approach that allows analyzing real-life situations. It gives an opportunity to approximate the learning process to the real practice of a specialist and puts students in the role of people who were faced with professional situation, complicated conflict cases during learning educational material. For example, study of disciplines "Advertising copywriting", "PR copywriting" is based on activity of real person or organization.

The work in small groups is an approach that structures form and content of practical lessons, gives an opportunity of collective solving a problem, provides formation of personal qualities and experience of social communication.

The role play / professional simulation is an approach that simulates situations, which concern speciality of students with the purpose to promote cognitive, evaluation and practical activity of participants of a lesson, to organize their interaction and communication.

The discussion is an approach that involves participants of a lesson to exchange their points of view on certain professional issues; contributes the development of critical thinking of students, the cultivation of skills to argue their own points of view; teaches to evaluate proposals of interlocutors and criticize their own points of views. Discussion provides clear feedback to all its participants, because a student not only criticizes and analyzes the position of the other participant, but also makes his or her own recommendations concerning a specific task or a problem.

The brainstorming is an approach that is used during practical session in the context of integration of vocational subject and English to solve urgent problems and the aim of which is to propose maximum variants of solution of a problem or a task for a limited period of time and choose the most optimal decision.

Інтегровані комунікації, 2016 
The presentation is used to show an audience the results of group work, reports concerning realization of individual tasks.

The project work involves the preparation of complex tasks by a student within the speciality "Advertising and public relations", their presentation and justification. In general, it is a final type of work that offers an opportunity to estimate in whole the knowledge of a student of a particular discipline [12].

Methods of teaching vocational subjects in English at the Institute of Journalism of Borys Grinchenko Kyiv University take into account Do Coyle's researches (Professor at the University of Aberdeen) that are connected with The 4Cs framework, which defines four elements of successful teaching specialized subjects in foreign languages:

1. Content is the object of knowledge, skills and understanding related with specific elements of certain program.

2. Communication is the use of language for acquiring of knowledge as well as its learning.

3. Cognition is the development of thinking skills that combine the formation of concepts (abstract and concrete), understanding and language.

4. Culture is the openness of alternative perspectives and collective understanding that deepen perception of a student.

The 4Cs framework for content and language integrated learning (CLIL) starts with content (such as subject matter, themes, cross-curricular approaches) and focuses on the interrelationship between content (subject matter), communication (language), cognition (thinking) and culture (awareness of self and "otherness") to build on the synergies of integrating learning (content and cognition) and language learning (communication and cultures). It unites learning theories, language learning theories and intercultural understanding [3].

Testing and assessment of student learning are realized with the help of the methods of control and self-control of learning and cognitive activities (oral, written, practical methods of control and self-control). Objects of control are a systematicity, activity and performance of a student during a semester, which concern a study of program material of a discipline in a class-room environment and accomplishment of tasks of individual work.

Methods of assessment of student's study consist of methods of oral control that is realized with the help of individual recitation, general questioning and interview; written control that is realized with the help of modular test; and also methods of self-control. Current control is carried out during practical session and the aim of which is to check the level of student's background for accomplishment of certain tasks.
Each module includes scores for student's current work during practical session, accomplishment of individual work, modular test. But the modular control of a student's knowledge is carried out after the study of educational material of certain module.

Assessment of student's study of theoretical material, practical tasks, individual work depends on the completeness of execution, creative approach to the tasks, quality, ownership of the work, timeliness of perform of learning tasks and initiative in training activities, which take into account the level of understanding and degree of acquirement of theory and methodology of studying problems and issues that are considered by a student in class-room environment or during individual work; uptake of factual learning content; knowing basic and additional bibliographical references; combining theory with practice during consideration of specific situations, solving learning problems that were proposed for individual work and tasks that were given for consideration in class; logic, structure, style of presentation of written materials and during performances in class, justification of own positions, consolidation of information and conclusions of a student.

As a result of study of disciplines "Advertising copywriting", "PR copywriting", "Public service announcement", "Theory of mass information", "Communication strategies" in English a student receives general and professional competencies that meet the requirements of higher education institution.

In particular, we emphasize worldview, civil and self-learning competencies that belong to general competencies.

The worldview competency provides formation of world outlook that concerns role of notions of certain advertising and PR disciplines in the world, the ability to analyze and evaluate social phenomena and processes, understanding and keeping to ethical norms and values, common culture.

The civil competency helps to a student to obtain the capacity of democratic communication and civil tolerance, the ability critically evaluate and solve political, social, cultural and ideological issues.

The self-learning competency enables to use traditional and modern information technologies in order to develop scientific and professional thesaurus, to analyze, organize and use scientific, educational and methodological information in professional sphere, to get a new knowledge, to improve student's organizational, self-learning, professional qualities.

Professional competencies include information, communicative, managerial, research and prognostic, design and creative, technological competencies.

The information competency allows to use the traditional and modern information technologies in 
professional activity, to gain knowledge about the specifics of establishment and functioning of mass media, to ensure effective cooperation with mass media, to choose mass media effectively (television, radio, press, outdoor advertising, Internet), to draft media plan, to combine all types of media buying for optimal results of advertising and PR campaigns.

The communicative competency teaches students written and oral communication in English, general culture of speech, professional communication in English, to work in a team, reasoning and to convince about their own ideas, to form their own style of communication, professional usage of non-verbal communication (sign system, appearance, facial expressions, gestures, demeanour, etc.), sociability, tolerance, artistry, public activity, to apply technologies of forming public opinion, to identify, analyze and prevent manipulative technologies.

The managerial competency provides insight into the basic algorithm of managerial activities (planning, organization, motivation, control), in particular how to plan, implement and accompany the advertising and PR campaigns for government organizations, commercial entities, non-governmental (non-profit) organizations; knowledge about evaluation techniques of effective advertising and PR activity, tools of management of reputation in normal as well as crisis situations, estimation of the state of reputation of companies, applying the methodology of effective negotiations in the fields of advertising, PR, mass communication.

The research and prognostic competencies develop the ability to perform market and research, forecasting and analytical activities, the ability to conduct qualitative and quantitative researches in the field of advertising and public relations, the ability to anticipate trends and prospects of development of the advertising and PR business in the context of globalization and world transformation, the ability to predict reputational risks and to work out plans for anti-crisis measures.

The design and creative competencies allow student to gain knowledge about nature of branding, naming, image technologies, receive the information about formation and development of leading brands, concepts of creation of corporate identity, opportunities for development of naming, technologies of elaboration of a strategy (mission, slogan, distinctive trademark, etc.) for commercial and non-profit organizations, creation of effective news hooks, scripts for events, organization of communication campaigns.

The technological competency enables to learn professional information technologies, SMM (social media marketing) management, to use the specified software in professional activity and private life, to acquire knowledge concerning practical principles of copywriting and mass communication, to produce advertising and PR products (texts, visual images, public speaking), to model advertising and PR messages according to the concepts of communication campaigns [12].

Conclusion. Methods of teaching vocational subjects in English that are applied at the Institute of Journalism of Borys Grinchenko Kyiv University were studied in the research. In particular, the process of teaching vocational subjects in English was described, methods of noticed practice are presented and analysed, competencies that a student gets after training are identified. Methods of teaching vocational subjects in English at the Institute of Journalism of Borys Grinchenko Kyiv University take into account the current requirements of a competitive environment to future specialist in the sphere of advertising and public relations, today's trends, experience of such practices at other higher education institutions. Methodology is based on leading concepts of content and language integrated learning that allows students comprehensively apply their knowledge and improve their skills in a globalized world.

Acknowledgments. The author would like to express appreciation to directorate of the Institute of Journalism of Borys Grinchenko Kyiv University, in particular Horbenko H.V., for initiative and contribution of such a practice like teaching advertising and public relations disciplines in English and colleagues of the Chair of Advertising and Public Relations for supporting this initiative.

\section{Reference list}

1. Rabota.ua [Job seeking website, requirements to a copywriter] [Electronic source]. - Reference: https:// rabota.ua/jobsearch / vacancy_list? regionId $=1 \&$ keyWords $=$ $\% \mathrm{~d} 0 \% \mathrm{ba} \% \mathrm{~d} 0 \% \mathrm{be} \% \mathrm{~d} 0 \% \mathrm{bf} \% \mathrm{~d} 0 \% \mathrm{~b} 8 \% \mathrm{~d} 1 \% 80 \% \mathrm{~d} 0 \% \mathrm{~b} 0 \% \mathrm{~d} 0 \% \mathrm{~b} 9 \%$ d1\%82\%d0\%b5\%d1\%80. - Accessed: 19.12.2016. - (Rus).

2. Brinton D. M. Content-based second language instruction / D. M. Brinton, M. A. Snow, M. B. Wesche. - New York : Newbury House Publishers, 1989. 241 p. - (Eng).

3. Coyle D., Hood P., Marsh D. CLIL : Content and Language Integrated Learning / D. Coyle, P. Hood, D. Marsh. - GB : Cambridge University Press, 2010,173 p. - (Eng).

4. De Escorcia B. A. Team Teaching for Students of Economics; a Columbian Experience [Text] / B. A. De Escorcia / / Common Ground : Shared Interests in ESP and Communication Studies. ELT documents. - Pergamon Press \& The British Council, 1984. - No 117. - P. 135-143. - (Eng).

5. Hutchinson T. English for Specific Purposes : A Learner-centered Approach [Text] / T. Hutchinson, A. Waters. - Cambridge : Cambridge University Press, 1987. - 315 p. - (Eng).

6. Mackenzie I. Content and Language Integrated Learning, Professional English, and the Future of ELT

Інтегровані комунікації, 2016 
[Electronic source] / I. Mackenzie. - Reference: http:// peo.cambridge.org /index.php?option=com_content\&view $=$ article\&id=50:content-and-language-integrated-learningprofessional-english-and-the-future-of-elt- \&catid=2:generalarticles\&Itemid=8. - Accessed: 15.12.2016. - (Eng).

7. Zvieriev I. D., Maksimova V. M. Interdisciplinary relationships in modern school / I. D. Zvieriev, V. M. Maksimova. - Moscow : Pedahohika, 1991. - 160 p. - (Rus).

8. Kulahin P. H. Interdisciplinary relationships in the process of study $/ \mathrm{P}$. H. Kulahin. - Moscow : Prosvieshchieniie, 1981. - 96 p. - (Rus).

9. Brandt A. Methods of teaching English [Electronic source] / A. Brandt. - Reference: https://greenforest.com. ua/journal/read/metodiki-vikladannya-anglijskoi-movi.

Accessed: 17. 12. 2016. - (Ukr).

10. Tarnopolskyi O.B. Methodology of teaching English for business communication / O.B. Tarnopolskyi, S.P. Kozhushko. - Kyiv : Lenvit, 2004. - 192 p. - (Rus).

11. Interdisciplinary coordination during teaching professionally oriented English and vocational subjects [Electronic source]. - Reference: http://lib.chdu.edu.ua/ pdf / monograf /14/13.pdf. - Accessed: 15.12.2016. - (Ukr).

12. Vernyhora S. M. Advertising copywriting : steering document for students of the first year of study of the speciality 6.030302 Advertising and public relations [Electronic source] / S. M. Vernyhora. - Kyiv : Borys Grinchenko Kyiv University, 2016. - 25 p. - Reference: http: / / elibrary.kubg.edu.ua/15874/1/\%D0\%9A\%D0\%B E\%D0\%BF\%D1\%96\%D1\%80\%D0\%B0\%D0\%B9\%D1\%82\% D0\%B8\%D0\%BD\%D0\%B3\%20\%D0\%B2\%20\%D1\%80\%D0 $\% \mathrm{~B} 5 \% \mathrm{D} 0 \% \mathrm{BA} \% \mathrm{D} 0 \% \mathrm{BB} \% \mathrm{D} 0 \% \mathrm{~B} 0 \% \mathrm{D} 0 \% \mathrm{BC} \% \mathrm{D} 1 \% 96$.pdf. Accessed: 15.12.2016. - (Ukr).

\section{Список літератури}

1. Rabota.ua [Платформа пошуку вакансій, вимоги до вакансії копірайтера] [Електронний ресурс]. - Режим доступу: https: / / rabota.ua/ jobsearch / vacancy_list?regionId=1\&ke yWords $=\% \mathrm{~d} 0 \%$ ba $\% \mathrm{~d} 0 \%$ be $\% \mathrm{~d} 0 \% \mathrm{bf} \% \mathrm{~d} 0 \% \mathrm{~b} 8 \% \mathrm{~d} 1 \% 80 \% \mathrm{~d} 0 \% \mathrm{~b} 0 \% \mathrm{~d} 0$ \%b9\%d1\%82\%d0\%b5\%d1\%80. - Дата доступу: 19.12.2016.

2. Brinton D. M. Content-based second language instruction / D. M. Brinton, M. A. Snow, M. B. Wesche. New York : Newbury House Publishers, 1989. - 241 p.

3. Coyle D.CLIL: Content and Language Integrated Learning / D. Coyle, P. Hood, D. Marsh. - GB : Cambridge University Press, 2010, - 173 p.

Вернигора С. Н., канд. наук из соц. коммуник, доцент, Институт журналистики

Киевского университета имени Бориса Гринченко
4. De Escorcia B. A. Team Teaching for Students of Economics; a Columbian Experience [Текст] / B. A. De Escorcia / / Common Ground : Shared Interests in ESP and Communication Studies. ELT documents. - Pergamon Press \& The British Council, 1984. - No 117. - P. 135-143.

5. Hutchinson T. English for Specific Purposes : A Learner-centered Approach [Текст] / T. Hutchinson, A. Waters. - Cambridge : Cambridge University Press, 1987. - 315 p.

6. Mackenzie I. Content and Language Integrated Learning, Professional English, and the Future of ELT [Електронний ресурс]. - Режим доступу: http:// peo.cambridge. org $/$ index.php?option $=$ com_content\&view $=$ article\&id $=50: \mathrm{c}$ ontent-and-language-integrated-learning-professional-englishand-the-future-of-elt-\&catid=2:general-articles\&Itemid $=8$. Дата доступу: 15.12.2016.

7. Зверев И. Д. Межпредметные связи в современной школе / И. Д. Зверев, В. Н. Максимова. - Москва, 1991. -160 c.

8. Кулагин П. Г. Межпредметные связи в процессе обучения /П. Г. Кулагин. - Москва : Просвещение, 1981. $96 \mathrm{c.}$

9. Брандт А. Методики викладання англійської мови [Електронний ресурс] / Анастасия Брандт. - Режим доступу: https://greenforest.com.ua/journal/read/metodikivikladannya-anglijskoi-movi. - Дата доступу: 17. 12. 2016.

10. Тарнопольский О. Б. Методика обучения английскому языку для делового общения / О. Б. Тарнопольский, С. П. Кожушко. - Киев : Ленвит, 2004. - 192 с.

11. Міжпредметна координація у навчанні професійно спрямованої англійської мови та фахових дисциплін [Електронний ресурс]. - Режим доступу: http: / /lib.chdu. edu.ua/pdf/monograf/14/13.pdf. - Дата доступу: 15. 12. 2016.

12. Вернигора С. М. Копірайтинг в рекламі : робоча програма для студентів за напрямом підготовки 6.030302 Реклама та зв'язки з громадськістю [1 курс]; галузь знань 0303 Журналістика та інформація [Електронний ресурс] / С. М. Вернигора. - Київ : Київський університет імені Бориса Грінченка, 2016. - 25 с. - Режим доступу: http: / / elibrary.kubg.edu.ua $/ 15874 / 1 / \% \mathrm{D} 0 \% 9 \mathrm{~A} \% \mathrm{D} 0 \% \mathrm{BE} \% \mathrm{D} 0 \% \mathrm{~B}$ F\%D1\%96\%D1\%80\%D0\%B0\%D0\%B9\%D1\%82\%D0\%B8\%D0 $\% \mathrm{BD} \% \mathrm{D} 0 \% \mathrm{~B} 3 \% 20 \% \mathrm{D} 0 \% \mathrm{~B} 2 \% 20 \% \mathrm{D} 1 \% 80 \% \mathrm{D} 0 \% \mathrm{~B} 5 \% \mathrm{D} 0 \% \mathrm{BA}$ $\% \mathrm{D} 0 \% \mathrm{BB} \% \mathrm{D} 0 \% \mathrm{~B} 0 \% \mathrm{D} 0 \% \mathrm{BC} \% \mathrm{D} 1 \% 96 . p d f$. - Дата доступу: 15.12.2016.

Подано до редакиії 25. 10. 2016 р.

\title{
МЕТОДИКА ПРЕПОДАВАНИЯ ПРОФЕССИОНАЛЬНЫХ ДИСЦИПЛИН НА АНГЛИЙСКОМ ЯЗЫКЕ В ИНСТИТУТЕ ЖУРНАЛИСТИКИ КИЕВСКОГО УНИВЕРСИТЕТА ИМЕНИ БОРИСА ГРИНЧЕНКО
}

\begin{abstract}
Аннотация. В статье представлена методика преподавания профессиональных дисциплин на английском языке, которая используется в Киевском университете имени Бориса Гринченко. Методы реализации указаной преподавательской практики продемонстрированы на примере ряда дисциплин спещиальности «Реклама и связи

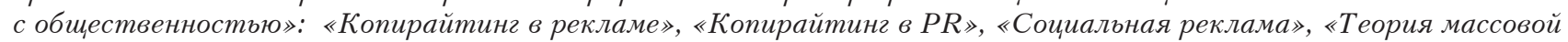
информации», «Коммуникационные стратегии».
\end{abstract}

Ключевые слова: методика, методы, преподавание, компетентности, реклама и связи с общественностью, профессиональные дисциплины на английском языке. 